Turkish Journal of Unmanned Aerial Vehicles

Türkiye İnsansız Hava Araçları Dergisi

https://dergipark.org.tr/tr/pub/tiha

e-ISSN 2687-6094

\title{
Hacim Hesaplarında İnsansız Hava Aracı (IHHA) Verilerinin Kullanılabilirliğinin Araştırılması
}

\author{
Vahit Şahin*1 ${ }^{*}$, Hacı Murat Yılmaz 2(i) \\ 1 Melikgazi Belediyesi Plan ve Proje Müdürlüğü \\ ${ }^{2}$ Aksaray Üniversitesi, Mühendislik Fakültesi, Harita Mühendisliği, Aksaray, Türkiye
}

\author{
Anahtar Kelimeler \\ İHA, \\ SíLO, \\ Fotogrametri, \\ Hacim Hesabi.
}

\begin{abstract}
ÖZ
Hacim hesapları birçok mühendislik çalışmasında kullanılmaktadır. Günümüzde Harita Mühendisliğinin İnşaat ve Madencilik sektöründeki en önemli iş kollarından birisi de hacim hesabıdır. Hacim hesapları jeodezik, fotogrametrik ve lazer tarama gibi farklı yöntemlerden elde edilen veriler kullanılarak yapılabilmektedir. Özellikle erişilmesi riskli ve zor bölgelerde hacim hesapları arazideki ölçmelerden ziyade bölgenin havadan veya yerden çekilen resimleri yardımıyla yapılması daha uygun olmaktadır. Günümüzde fotogrametri, haritacılık alanında oldukça önemli bir yere sahiptir. Fotogrametrik harita üretiminde farklı platformlar kullanılarak görüntü alımı gerçekleștirilmektedir. Gelişen teknoloji havadan fotoğraf temininde yeni alternatifler ortaya çıkarmıștır. Yaşanan teknolojik gelişmeler neticesinde uzaktan algılama ve fotogrametri ile üretilen verilerde, İnsansız Hava Araçları (İHA) kullanılmaya başlanmıştır. Bu çalışmada son yıllarda birçok konuda uygulama alanı bulan İHA verileri kullanılarak yapılan hacim hesaplarının farklı açılardan analizi yapılmıştır. Hacmi bilinen tarımsal ürün depolama tesisi (SILO) ve bir dolgu alanının hacmi İHA verileri yardımıyla hesaplanmıștır. Yapılan hesaplamada düzgün geometrik yapıya sahip SìLO’nun hacmi \%98 doğrulukla, düzgün geometrik yapıya sahip olmayan dolgu alanı hacmi \%93.57 doğrulukla hesaplanmıștır.
\end{abstract}

\section{Investigation of the Usability of Unmanned Aerial Vehicle (UAV) Data in Volume Calculations}

Keywords

$\mathrm{UAV}$,

SíLO,

Photogrammetry,

Volume calculation.

\begin{abstract}
Volume calculations are used in many engineering studies. Today one of the most important business lines of Surveying Engineering in the construction and mining sector is volume calculation. Volume calculations can be made using data obtained from different methods such as geodetic, photogrammetric and laser scanning. Especially in areas that are risky and difficult to access, it is more appropriate to make volume calculations with the help of aerial or ground photographs of the region rather than measurements on the field. Today photogrammetry has a very important place in the field of cartography. In the production of photogrammetric maps, images are acquired using different platforms. Developing technology has revealed new alternatives in aerial photography. As a result of the technological developments experienced, Unmanned Aerial Vehicles (UAV) have started to be used in the data produced by remote sensing and photogrammetry. In this study, the volume calculations made using UAV data which have found application in many subjects in recent years, were analyzed from different perspectives. The volume of a known agricultural product storage facility (SILO) and the volume of a fill area were calculated with the help of UAV data. In the calculation made, the volume of the SILO with a regular geometric structure was calculated with an accuracy of $98 \%$, and the volume of the filling area without a regular geometric structure was calculated with an accuracy of $93.57 \%$.
\end{abstract}




\section{GİRiş}

Hacim hesaplama işlemleri birçok mühendislik disiplininde yaygın olarak kullanılmaktadır. Günümüzde Harita Mühendisliğinin inşaat, yol projeleri, baraj projeleri, madencilik sektörü vb. iş alanlarında önemini artıran önemli iş kolları arasında hacim hesaplamaları da yer almaktadır (Yakar vd., 2009; Seki, 2017). Hacim hesapları birçok farklı yöntem ile elde edilen veriler yardımıyla yapılabilmekte olup, bu yöntemlere jeodezik, fotogrametrik ve lazer tarama örnek olarak gösterilebilir. Özellikle insan hayatını tehlikeye sokan ve erişilmesi riskli ve zor bölgelerde hacim hesaplamaları gelişen teknolojik gelişmeler doğrultusunda, bölgenin havadan veya yerden çekilen fotoğrafları kullanılarak yapılabilmektedir.

Farklı mühendislik problemlerinin çözümünde fotogrametrik tekniklerin kullanımı yaygınlaşmıştır. Farklı özelliklere sahip doğal ve yapay yapıların fotogrametrik amaçlarla fotoğraflarının elde edilmesinde insansız hava araçları önemli katkılar sağlamıştır (Uysal vd.,2015). Yaşanan teknolojik gelişmeler doğrultusunda, fotogrametri yöntemleri haritacılık alanında önemini her geçen gün artırmaktadır. Fotogrametrik yöntemler kullanılarak harita üretimi için farklı platformlardan elde edilen görüntüler kullanılmaktadır (Yakar vd., 2009; Yılmaz \& Yakar, 2008). Gelişen teknoloji havadan görüntü alımında kullanılan uçak, helikopter vb. hava taşıtlarına yeni alternatifler ortaya çıkarmıştır. Bu bağlamda, İnsansız Hava Aracı (İHA) teknolojisi yeni bir görüntü alım platformu olarak karşımıza çıkmaktadır (Aktaş vd., 2016). Yaşanan teknolojik gelişmeler neticesinde uzaktan algılama ve fotogrametri ile üretilen verilerde, hız ve maliyet açısından sağladı̆̆ı avantajlar ile İHA kullanımı her geçen gün artmaktadır.

Günümüzde İHA kullanımı hızla yaygınlaşmaktadır. Bunun nedenleri arasında; düşük maliyetle üretilebilmeleri, onarım-bakım masraflarının düşük olması, insan hayatını tehlikeye atma olasılığı bulunan görevleri yerine getirebilmeleri, kaliteli ve hassas veri üretebilmeleri, düşük emisyona sahip olmaları şeklinde sıralanabilir (Yılmaz vd., 2018).

İnsanız Hava Araçları, içerisinde uçuş ekibi (pilot) olmadan aerodinamik uçuş prensiplerine göre aralıksız olarak otomatik ya da yarı otomatik uçabilme özelliğine sahip araçlardır (Saripalli vd., 2003). İHA sistemleri son birkaç yıl içerisinde sivil kullanıma uygun hale getirilmiştir. İHA sayılarının her geçen gün artması, farklı iş sahaları arasında kullanılmasını yaygınlaştırmıștır (Yanmaz vd., 2017). İHA'nın yenilikçi bir iş modeli olarak yaygınlaşması neticesinde, hava fotogrametrisi, havadan ölçme, uzaktan algılama, geomatik (harita, kadastro, jeodezi ve fotogrametri) uygulamalarının bir parçası haline geldiği artık kanıtlanmış durumdadır. Büyüklüğü 10.1 milyar USD olan global İHA pazarının, genel ekonomik büyümenin aksine \%8.12 seviyesinde büyüyerek 2020 itibariyle yaklaşı 15 milyar USD genişlemeye ulaşması beklenmektedir. İHA fotogrametrisi (Structure from Motion-SfM) özellikle tarım, madencilik, havadan fotoğraflama ve emlak sektörlerinde kendine yer bulmuştur. Harita, kadastro ve planlama işlerinde ise temel konunun mülkiyet hakkı ve bunun belirlenmesi olması sebebiyle daha temkinli davranılmakla birlikte, İHA'nın uygulama olanakları konusunda özellikle doğruluk, uygunluk, ölçülebilirlik (izleme, kalibrasyon, kayıt vb.) bakımından çok sayıda kurum, firma ve araştırmacının derinlemesine çalışması sürmektedir. Ayrıca, yapılan uygulamalardan edinilen tecrübelerle birlikte İHA kullanılarak ölçme konusunda kalite, güvence ve altyapı oluşturma ihtiyacı hızla artmaktadır (Torun, 2017).

Yakar ve Doğan (2017), yaptıkları çalışmada Akhayat obruğunun değişik açılardan çekilen İnsansız Hava Aracı görüntüleri ile üç boyutlu modelleme çalışmasını gerçekleştirerek kontrol noktalarındaki karesel ortalama hatayı $1.64 \mathrm{~cm}$ olarak tespit etmişlerdir. Yapılan çalışmada ayrıca yer örnekleme aralığı 1.37 $\mathrm{cm} /$ piksel olan ortofoto ve yer örnekleme aralığı 11 $\mathrm{cm} /$ piksel olan Sayısal Yükseklik Modeli üretimi de yapılmıştır.

Tercan (2018), yaptı̆̆ı çalışmada İnsansız Hava Araçları ile Antalya şehrinde belirlemiş olduğu bir karayolunda \%85 enine, \%65 boyuna bindirme oranları ile $140 \mathrm{~m}$ yükseklikten uçuş yapmıştır. Uçuş İşlemi sonrası büro çalıșması ile Sayısal Yükseklik Modeli ve ortofoto görüntü elde etmeyi amaçlamıştır. Ayrıca çalışma esnasında 7 tane yer kontrol noktasının tesisini Cors-RTK yöntemi ile gerçekleştirmiştir. İHA ile yapılan uçuş işlemi sonrası nokta bulutunu sınıflandırarak zemindeki nokta verilerine ulaşmıștır. Çalışma alanı olarak belirlenen karayolunda gerçekleştirilen jeodezik işlemler neticesinde ise yersel ölçümler ile karşılaştırması sonucunda toprak zeminde $7.32 \mathrm{~cm}$, sert zeminde $3.96 \mathrm{~cm}$ ve mekânsal alanlarda ise $4.9 \mathrm{~cm}$ yatay doğruluğa ulaşmıştır. Yaptığı çalışma sonucunda Sayısal Yükseklik Modeli, Sayısal Arazi Modeli ve ortofoto üretiminin bitki örtüsünün seyrek olduğu ve düz arazi yüzeylerinde kullanılabileceğini belirtmiștir.

Gençerk (2016), yaptığı çalışmada, İHA ile elde edilen fotoğraflar kullanılarak kazı-dolgu ve kübaj hesaplama işlemlerinde, arazi ve saha çalışmaları neticesinde ulaşılan doğruluğun mühendislik projelerinde kullanılabilirliğini araştırmıștır. Yaptığı araștırma sonucunda elde ettiği ortofoto, Sayısal Yükseklik Modeli ve Sayısal Arazi Modelinin $5 \mathrm{~cm}$ çözünürlüğe sahip olduğunu tespit etmiştir. Çalışma kapsamında elde ettiği ürünler üzerinde kübaj hesabı, en kesit ile boy kesit alımı ve analizlerini yapmış ve süre, doğruluk ve mali yönlerden yorumlayarak mühendislik çalışmalarında kullanılabileceğini ortaya koymuştur.

Özemir ve Uzar (2016), yaptıkları bir çalışmada Gaziantep 5. Organize Sanayi Bölgesinde fotogrametrik veri üretimi için İnsansız Hava Aracı ile elde edilen fotoğrafları kullanarak yer örnekleme aralığı $3.53 \mathrm{~cm}$ olan ortofoto ve $7.06 \mathrm{~cm}$ olan Sayısal Yükseklik Modeli elde etmişlerdir. İnsansız Hava Araçlarının insan hayatı için tehdit oluşturan yerlerde uzaktan veri elde etme firsatı sunarak anlık çözüm üretebilen tam zamanlı veri kontrolü ile veri üretimini gerçekleştirdiği sonucuna ulașmıșlardır.

Yakar vd. (2015), yaptıkları çalışmada, Bezariye Hanının fotogrametrik yöntemlerle ölçülmesi, üç boyutlu modelinin üretilmesi ve elde edilen 3 boyutlu modellerin yapının tarihi dokusuna uygun olarak restore edilebilmesi için sağlayacağı avantajları incelemişlerdir. Ayrıca elde edilen bu üç boyutlu modellerin İHA'lar ile fotogrametrik teknikler kullanılarak yapılması ile resim elde etme olanaklarını artırması ve dolayısı ile 
dokümantasyonun daha gerçekçi ve kapsamlı olduğunu vurgulayarak, fotogrametrik tekniklerin İHA yardımıyla farklı disiplinlerde de kullanılabileceği sonucuna ulaşmışlardır.

Yılmaz vd. (2018), yaptıkları çalışmada İnsansız Hava Aracı ile elde edilen verileri kullanarak Aksaray Üniversitesi Kampüsünün ortofoto görüntüsünün üretimini gerçekleştirmişlerdir. Yapılan çalışmada Topcon GR3 GPS alıcısı ile WGS 84 koordinat sisteminde yeterli sıklıkta yer kontrol noktası tesisini gerçekleştirmişlerdir. Havadan resimlerin çekilmesi için 12 MP çözünürlüklü Ricoh marka kamera donanımına sahip Smartplanes marka İnsansız Hava Aracı kullanılmışlardır. Uçuş işlemlerini tamamlandıktan sonra elde edilen verileri Virtual Surveyor İHA yazılımı ile değerlendirerek çalışma alanının Sayısal Yükseklik Modeli ve ortofoto haritasını üretmişlerdir. Ayrıca elde ettikleri verilerin doğruluğunun kontrol edilmesi amaciyla üç boyutlu model ve ortofoto haritada beş noktada yatay uzunluk ve beş noktada özellikle yapılarda düşey uzunlukların ölçümünü yapmışlardır. Yaptıkları çalışma sonucunda elde ettikleri ürünlerdeki ortalama konum hatasını $\pm 2.38 \mathrm{~cm}$, ortalama yükseklik hatasını ise $\pm 9.94 \mathrm{~cm}$ olarak hesaplamıșlardır. Yaptıkları çalışmada üç boyutlu modellerinin üretilmesinde düşey resimlerin yanında eğik resimlerinde çekilmesinin önem arz ettiğini belirterek çalışma alanının eğik resimleri de çekilerek konum doğruluğunun, yükseklik doğruluğundan daha yüksek çlktığı sonucuna ulaşmışlardır. Yaptıkları çalışma sonucunda klasik hava fotogrametrisi ile kıyaslandığında Sayısal Arazi Modellerinin, Sayısal Yükseklik Modellerinin, küçük alanlarda halihazır harita üretimin ve birçok disiplin tarafından kullanılan ortofoto harita üretiminin İHA ile daha ekonomik ve kısa sürede uygun yükseklik ile konum hatalarına sahip olarak elde edilebileceği sonucuna ulaşmışlardır.

Kaya vd. (2019), yaptıkları çalışmada Harran Üniversitesi Osmanbey Kampüsü'nde yer alan göletin kapasitesi ve hacminin hesaplaması çalışması ile hacim hesaplamalarında İHA kullanımını araştırmışlardır. Yaptıkları çalışmada Harran Üniversitesi Yapı İşleri ve Teknik Daire Başkanlığı'ndan aldıkları referans bilgi doğrultusunda göletin planlanan su yüksekliğinin $1.40 \mathrm{~m}$ olduğu ve $1.40 \mathrm{~m}$ su yüksekliği için toplam hacmini ise $23.430,09 \mathrm{~m}^{3}$ bilgisini belirterek elde ettikleri değeri gerçek hacim değeri olarak kabul etmişlerdir. Çalışma devamında temizlenme çalışmaları nedeniyle boşaltılan havuzda Cors-GPS Yöntemi ile gölete ait tüm kırık noktalar ve hem üst seviye üzerinden hem de tabandan ölçümleri yapılmış ve çalışma alanı olan gölette hacim hesaplanması için 59 adet noktada ölçüm işlemi yapılmıştır. Havadan fotoğrafların elde edilmesi amacıyla üzerinde 20.2 megapiksel kompakt bir kameraya sahip, 8 pervaneli TURKUAV marka İHA ile boş vaziyetteki gölete ait 247 adet resim çekilmiștir. Elde edilen resimlerden uygun olanları Pix4D yazılımında değerlendirmesi yapılmış ve çalışma bölgesine ait dokuz milyonun üzerinde noktaya sahip veri üretilmiştir. Yaplan çalışma ile göletin gerçek hacmi ile jeodezik yöntemle elde edilen hacim değeri arasında \%4.07, göletin gerçek hacmi ile fotogrametrik yöntem ile elde edilen hacim değeri arasında ise \%0,50 fark olduğu tespit edilmiștir. Yapılan çalışma sonucunda fotogrametrik yöntem ile hacim hesaplamasının jeodezik yöntemlere göre iş gücü, maliyet ve zaman açısından daha avantajlı olduğu sonucuna ulașmıșlardır.

Ulvi (2018), yaptığı çalışmada İHA kullanarak fotogrametrik teknikler ile hacim hesaplamasını araştırmıştır. Çalışma kapsamında Selçuk Üniversitesi Alaaddin Keykubat Kampüsü içerisinde 20 m x 18 m x 3 $\mathrm{m}$ boyutlarına sahip bölge çalıșma alanı olarak belirlenmiştir. Çalışma kapsamında ilk olarak hacim hesabı yapılacak bölgede 8 adet yer kontrol noktası tesisini gerçekleștirmiştir. Yer kontrol noktalarının tesisi işleminin ardından İHA ile 20 m yükseklikten 85 adet fotoğraf çekimini gerçekleştirmiş ve elde ettiği fotoğraflardan 24 tanesini değerlemede kullanılmıştır. Arazi çalışması ile ede edilen yer kontrol noktaları ve hava fotoğrafları verileri büro çalışması esnasında Netcad ve Photomodeler programlarında değerlendirilmiş ve hacim hesaplaması gerçekleştirilmiştir. Yaptığı hesaplamalar neticesinde klasik yöntem ile çalışma bölgesinde toplam hacmi 286 $\mathrm{m}^{3}$ olarak hesaplamış ve klasik yöntem ile hacim hesaplamasının toplam 220 dakikada tamamlandığını belirtmiştir. Aynı çalışma kapsamında fotogrametrik yöntem ile çalışma bölgesinde toplam hacmi $287.94 \mathrm{~m}^{\wedge} 3$ olarak hesaplamış ve fotogrametrik yöntem ile hacim hesaplamasının toplam 60 dakikada tamamlandığını belirtmiştir. Yaptığı çalışma kapsamında klasik yöntem ile elde edilen toplam hacim ile fotogrametrik yöntem ile elde edilen toplam hacim arasında $1.94 \mathrm{~m}^{\wedge} 3$ fark elde etmiş ve iki işlem arasında doğruluk analizini \%99.33 olarak hesaplamıştır. Yaptığı çalışma neticesinde fotogrametrik yöntem ile hacim hesaplama işlemlerinin klasik yöntemler ile kıyaslandığında yeterli doğruluk oranına sahip olduğu, zaman ve maliyet yönlerinden ise fotogrametrik yöntemler ile hacim hesaplama işlemlerinin klasik yöntemler ile yapılan hacim hesaplamaları işlemlerine kıyasla daha avantajlı olduğu sonucuna ulaşmıştır.

Ulvi vd. (2020), yaptıkları çalıșmada İnsansız Hava Aracı ve yersel fotogrametrik teknikler kullanarak Aksaray Kızıl Kilise'nin 3 boyutlu nokta bulutu ve modelinin üretilmesini araştırmışlardır. Yapılan çalışmada Kızıl Kilise'nin dış cephe çizimleri, nokta bulutları ve 3 boyutlu modeli elde edilmiştir. Çalışma esnasında ilk olarak detay nokta alımı için gerekli sabit nokta tesisi için araştırma çalışmaları yapılmış ve 4 noktaya poligon tesisi tamamlanmıştır. Poligonların tesisi işleminin ardından kilise yüzeyinde homojen dağılımda 18 adet kontrol noktası seçilerek bu noktaların jeodezik koordinatları lokal olarak hesaplanmıştır. Poligon tesisi ve kontrol noktalarının hesaplanmasının ardından kilisenin yer bazlı ve havadan fotoğraf çekimi işlemi yapmışlardır. Havadan yapılan fotoğraf çekimlerinde 30 m yükseklikten Phantom 3 Professional İnsansız Hava Aracında entegreli olan 12.76 megapiksel çözünürlüğe sahip Sony EXMOR kamera kullanılmış ve farklı açlardan bindirmeli olarak fotoğraf çekimi yapılmıştır. Elde edilen veriler Photomodeler UAS ve Agisoft Photoscan yazılımlarında değerlendirilmiş ve çalışma alanının üç boyutlu modelleri elde edilmiştir. Elde ettikleri 3 boyutlu modellerin doğruluk analizini ise jeodezik ölçme aleti ile temin edilen koordinat verileri ile 3 boyutlu modellerden elde edilen test verileri karşılaştırılmıștır. Ölçme aleti ile elde edilen koordinatlar 
kesin koordinatlar olarak kabul edilmiș ve aynı koordinat değerleri 3 boyutlu modellemede kullanılan her iki yazılımda da değerlendirilmiş ve farkları hesaplanarak noktaların karesel ortalama hatalarına ulaşılmıștır. Yapılan karesel ortalama hesabı sonucunda $\mathrm{x}, \mathrm{y}, \mathrm{z}$ koordinatlarında ortalama konum hatası; Photomodeler yazılımında $\pm 20.4 \mathrm{~mm}$ ve Agisoft yazılımında $\pm 17.1 \mathrm{~mm}$ olarak hesaplamışlardır. Yaptıkları çalışma sonucunda fotogrametri tekniği kullanımının uzun süredir kültürel ve tarihi eserlerin belgelenmesinde ve rölöve çalışmalarında klasik yöntemlere göre kullanıcıya maliyet, zaman, hassasiyet ve görsellik olarak avantajlar sağladığı sonucuna ulaşmışlardır.

Takeuchi ve Nakanishi (2019), yaptıkları bir çalışmada nehir yataklarında bulunan maddelerin boyutlarını tespit edebilmek için klasik yöntemlerin kullanımının, kısa vadede büyük alanları araștırmanın ve konumsal dağılımı hakkında doğru bilgi edinmenin zorluklarına değinerek, görüntü işleme teknikleri veya yüksek çözünürlüklü topografik verileri kullanmanın etkin bir yöntem olduğunu belirtmişlerdir. Çalışma kapsamında İHA verileri yardımıyla çakıl ve kumun parçacık boyutunu tahmin etmek için Yapay Sinir Ağ Modeli üretmişlerdir. İHA görüntüleri yardımıyla elde ettikleri Sayısal Arazi Modelinde yüksek tahmin doğruluğu sağlamışlardır. Çalışmada önerilen Yapay Sinir Ağı Modelleri, nehir yatağı parçacıklarının çapını yaklaşık $-0,7 \mathrm{~mm}$ ortalama hata ve yaklaşı $16,3 \mathrm{~mm}$ ortalama standart sapma oranı ile yüksek doğrulukla tespit etmişlerdir.

Becker vd. (2018), yaptıkları çalışmada İHA ile elde edilen resimlerden üretilen görüntüleri Pix4D programında değerlendirerek faklı yoğunluklarda üretilen nokta bulutlarının sınıf etiketlerini elde etmek için uygun bir yöntem olduğunu ortaya koymuşlardır. Çalışma kapsamında geometrik özelliklere ek olarak renk bilgisini de dahil ederek anlamlı sınıfların tespitinde ve doğrulukta önemli bir artış sağlamışlardır. Yaptıkları çalışmada sınıflandırmada makine öğrenmesini yöntemini kullanmışlardır. Makine Öğrenimi için Random Fores ve Gradient Boosted Trees metotları ile test verilerini sınıflandırmışlardır. Çalışma sonucunda Gradient Boosted Trees metotu kullanımının daha başarılı sonuç verdiğine değinerek daha fazla eğitim verisi ile daha başarı sonuçlar elde etmişlerdir. Sonuç olarak bina ve diğer sınıfları daha doğru tespit etmişlerdir.

Bu çalıșmada son yıllarda birçok konuda uygulama alanı bulan İHA verileri kullanılarak hacmi bilinen tarımsal ürün depolama tesisi (SÍLO) ve bir dolgu alanının Agisoft Metashape, Pix4Dmapper ve 3 DF Zephyr programlarinda 3 boyutlu modellerinin üretilmesi ve hacim hesaplamalarının yapılması amaçlanmıştır.

\section{UYGULAMA}

Mühendislik çalışmalarında büyük önem arz eden hacim hesaplamaları literatürde jeodezik yöntemler ve fotogrametri yardımıyla yapılmıştır. Yaşanan teknolojik gelişmeler doğrultusunda kullanım alanı her geçen gün artan İHA'ların hacim hesaplamalarında kullanımı da gün geçtikçe artmaktadır. Bu çalışmada iki farklı objenin hacmi İHA verileri yardımıyla hesaplanmıştır.

\subsection{Tarımsal Ürün Depolama Tesisi (SİLO) Hacim Hesaplama İşlemi}

İHA'ların hacim hesaplarında kullanılabilirliğinin araştırılmasında ilk işlem olarak teknik bilgileri ve hacmi bilinen SİLO'ların hacmi hesaplanmıștır. Yapılan hacim hesaplama işlemi arazi çalışması ve büro çalışması olmak üzere iki aşamadan oluşmakta olup, aşağıda açlklanmıştır.

\subsubsection{Arazi Çalışması}

Hacmi hesaplanacak SİLO’lar Kayseri İli, Talas İlçesi, Kamber Mahallesi, Topraktepe Mevkiinde yer alan $31.000 \mathrm{~m}^{2}$ alana sahip 0 Ada 1921 Parsel üzerinde inşa edilen Ruhbaş Tarım Ürünleri Lisanslı Depoculuk A.Ş. firmasına sahip depolama tesisi içerisinde yer almakta olup, çalışma alanına ait fotoğraf Şekil 1'de verilmiştir.

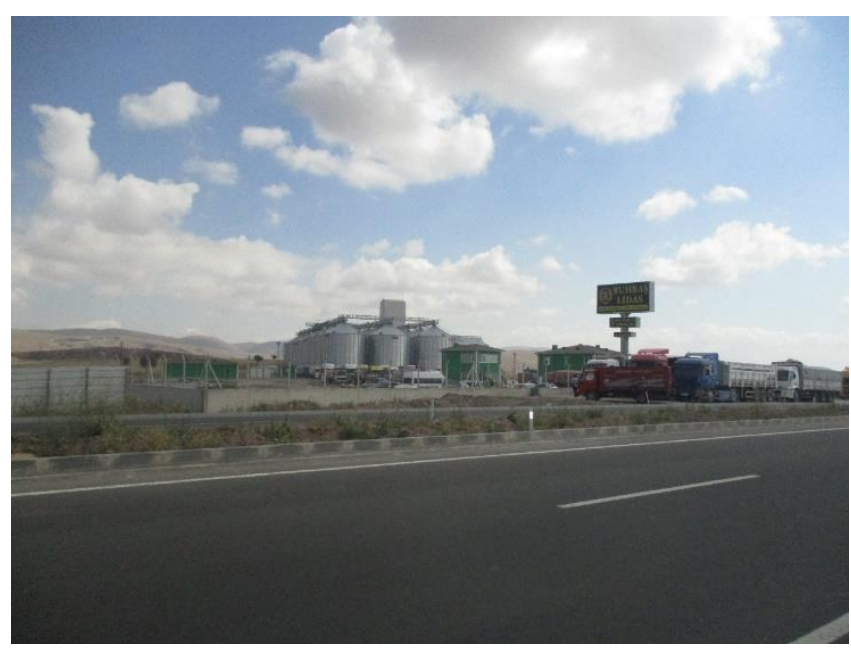

Şekil 1. Hacim Hesabı Yapılacak Çalışma Alanı.

Yapılan arazi çalışmasında ilk işlem olarak Comnav T300 marka GPS ile 6 adet yer kontrol noktası tesis edilmiş olup, elde edilen veriler aşağıda Tablo 1'de gösterildiği üzere verilmiştir.

Tablo 1. SİLO Hacim Hesabı İçin Tesisi Edilen Yer kontrol Noktaları.

\begin{tabular}{rccc}
\hline YKN NO & X DEĞERI & Y DEĞERİ & Z DEĞERİ \\
\hline P.101 & 480865.394 & 4277377.460 & 1592.239 \\
P.102 & 480904.210 & 4277393.829 & 1591.323 \\
P.103 & 480963.198 & 4277459.617 & 1591.240 \\
P.104 & 481062.917 & 4277567.102 & 1593.404 \\
P.105 & 481006.592 & 4277629.179 & 1594.737 \\
P.106 & 480918.779 & 4277501.624 & 1591.470 \\
\hline
\end{tabular}

Yer kontrol noktalarının tesis işlemi tamamladıktan sonra DJI Phantom 4 Pro marka İHA ile uçuş ișlemleri gerçekleştirilmiştir. İHA uçuş yüksekliği sağlıklı veri elde edilebilmesi amacıyla $75 \mathrm{~m}$ olarak belirlenmiş ve uçuş süresi yaklaşık 25 dakika sürmüştür. Elde edilecek hava fotoğraflarında $\% 80$ ön ve \%60 yan bindirme oranı belirlenmiş ve 2 kez uçuş yapılarak, çalışma alanının enine belirlenen güzergahında 125 adet; boyuna belirlenen güzergahında ise 123 adet olmak üzere toplam 248 adet fotoğraf elde edilmiştir. Yapılan double 
grid uçuşu işleminde Pix4Dcapture yazılımı kullanılmıştır. Uçuş işlemlerinde kullanılan DJI Phantom 4 Pro marka İHA'nın sağladığı yer örnekleme aralığının (m / 36.5) cm / piksel olduğu teknik kataloğu üzerinden incelenmiştir. Çalışma kapsamında İHA uçuşunun 75 m yükseklikten gerçekleştirilmiş olması nedeniyle yer örnekleme aralığı $2.05 \mathrm{~cm} /$ piksel olarak kabul edilmiștir. İHA ile yapılan uçuşlara ait örnek fotoğraf Şekil 2' de verilmiştir.

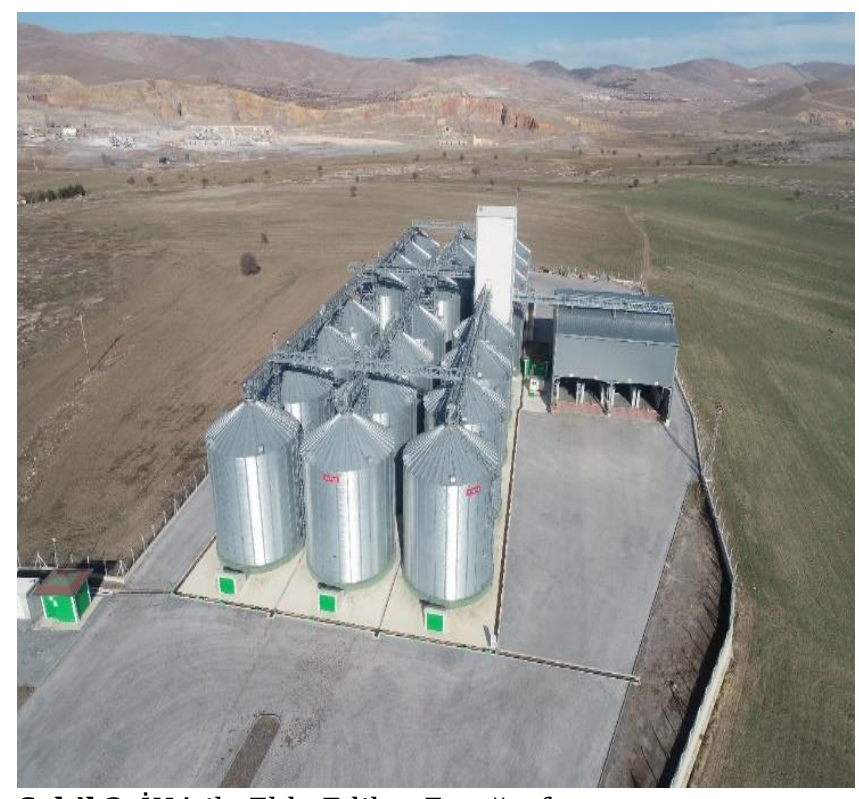

Şekil 2. İHA ile Elde Edilen Fotoğraf.

\subsubsection{Büro Çalışması}

Saha çalıșmaları sonucu elde edilen veriler büro ortamında 3 boyutlu modellerin üretilmesi aşamasında kullanılmıştır. 3 boyutlu modellerin elde edilmesi ve hacim hesabının yapılması için Pix4Dmapper, Agisoft Metashape ve 3 DF Zephyr programları kullanılmıștır.

Büro çalışmasında ilk olarak arazi çalışması ile elde edilen ve yukarıda Tablo 1'de gösterilen yer kontrol noktaları Pix4Dmapper, Agisoft Metashape ve 3 DF Zephyr programlarına aktarılmış ve hata payları incelenmiştir. Yapılan incelemede yer kontrol noktalarının Pix4Dmapper programında ortalama $\mathrm{X}$ değeri hata payı $\sim 1.2 \mathrm{~cm}$, Y değeri hata payı $\sim 1.3 \mathrm{~cm}$ ve Z değeri hata payı ise $\sim 0.4 \mathrm{~cm}$ olarak tespit edilmiştir. Agisoft Metashape programında ise yer kontrol noktalarının nihai ortalama hata payı $\sim 0.6 \mathrm{~cm}, 3 \mathrm{DF}$ Zephyr programında ise yer kontrol noktalarının nihai ortalama hata payı $\sim 1.2 \mathrm{~cm}$ olarak tespit edilmiştir.

Büro çalıșmaları ișleminde ikinci olarak SíLO'ların teknik kataloğu incelenmiştir. SİLO'ların teknik kataloğu üretici firma olan Mysilo firmasından temin edilmiş ve hacim hesabı yapılacak SİLO'ların model numarasının 1415 olduğu öğrenilmiștir. Teknik katalogda yer alan bilgilere göre Model 1415 numaralı SİLO'nun $12.83 \mathrm{~m}$ taban çapı, 15 adet ring, 12.68 m saçak yüksekliği, 16.29 $\mathrm{m}$ tepe yüksekliği, $1.782 \mathrm{~m}^{3}$ toplam kapasiteye sahip olduğu ve 1.512 ton buğday, 1.360 ton misır veya 1.209 ton arpa kapasitesine sahip olduğu görülmüş olup, SİLO'ların teknik kataloğu Şekil 3' te verilmiştir.

\begin{tabular}{|c|c|c|c|c|c|c|c|c|}
\hline $\begin{array}{l}\text { Çap } \\
\text { m (ft) }\end{array}$ & Model & $\begin{array}{l}\text { Ring } \\
\text { Sayis! }\end{array}$ & $\begin{array}{c}\text { Saçak } \\
\text { Yüksekliği } \\
\text { (m) }\end{array}$ & $\begin{array}{c}\text { Tepe } \\
\text { Yuksekligi } \\
\text { (m) }\end{array}$ & $\begin{array}{c}\text { Kapasite } \\
\left(\mathrm{m}^{\prime}\right)\end{array}$ & $\begin{array}{c}\text { Kapasite } \\
\text { Bugiday } \\
\text { (ton) }\end{array}$ & $\begin{array}{l}\text { Kapasite } \\
\text { Misir } \\
\text { (ton) }\end{array}$ & $\begin{array}{l}\text { Kapasite } \\
\text { Arpa } \\
\text { (ton) }\end{array}$ \\
\hline \multirow{27}{*}{$\begin{array}{l}12,83 \\
(42)\end{array}$} & 1408 & 8 & 6,76 & 10,38 & 1.018 & 863 & 777 & 690 \\
\hline & 1408 & 9 & 7,61 & 11.22 & 1.127 & 856 & 860 & 765 \\
\hline & 1410 & 10 & 8.45 & 12.07 & 1.236 & 1.048 & 943 & 839 \\
\hline & 1411 & 11 & 9,30 & 12.91 & 1.345 & 1.141 & 1.027 & 913 \\
\hline & 1412 & 12 & 10,14 & 13,76 & 1455 & 1234 & 1.110 & 987 \\
\hline & 1413 & 13 & 10,99 & 14,60 & 1.564 & 1.328 & 1.184 & 1.061 \\
\hline & 1414 & 14 & 11,83 & 15,45 & 1673 & 1.419 & 1.277 & 1.135 \\
\hline & 1415 & 15 & 12,68 & 16.29 & 1.782 & 1.512 & 1.360 & 1.209 \\
\hline & 1416 & 16 & 13,52 & 77,14 & 1892 & 1604 & 1.444 & 1.283 \\
\hline & 1417 & 17 & 14,37 & 17.98 & 2.001 & 1.697 & 1.527 & 1.357 \\
\hline & 1418 & 18 & 15,21 & 18,83 & 2.110 & 1.789 & 1.610 & 1.432 \\
\hline & 1419 & 19 & 16,06 & 19,67 & 2219 & 1.882 & 1.694 & 1.506 \\
\hline & 1420 & 20 & 16,90 & 20.52 & 2329 & 1.975 & $1.7 m 7$ & 1.580 \\
\hline & 1421 & 21 & 17,75 & 21,36 & 2.438 & 2067 & 1.861 & 1.654 \\
\hline & 1422 & 22 & 18,59 & 2221 & 2547 & 2.160 & 1.944 & 1.728 \\
\hline & 1423 & 23 & 19,44 & 23.05 & 2656 & 2.253 & 2.027 & 1.802 \\
\hline & 1424 & 24 & 20,28 & 23.90 & 2766 & 2.345 & 2.111 & 1.876 \\
\hline & 1425 & 25 & 21,13 & 24,74 & 2875 & 2438 & 2.194 & 1.950 \\
\hline & 1426 & 26 & 21,97 & 25,59 & 2984 & 2531 & 2277 & 2024 \\
\hline & 1427 & 27 & 22,82 & 26,43 & 3.093 & 2623 & 2.361 & 2.099 \\
\hline & 1428 & 28 & 23,66 & 27.28 & 3.203 & 2.716 & 2.444 & 2.173 \\
\hline & 1429 & 29 & 24,51 & 28,12 & 3.312 & 2808 & 2528 & 2.247 \\
\hline & 1430 & 30 & 25,35 & 28,97 & 3.421 & 2901 & 2.611 & 2.321 \\
\hline & 1431 & 31 & 26,20 & 29.81 & 3.530 & 2994 & 2.694 & 2.395 \\
\hline & 1432 & 32 & 27,04 & 30,66 & 3640 & 3086 & 2.778 & 2.469 \\
\hline & 1433 & 33 & 27.89 & 31,50 & 3749 & 3179 & 2861 & 2.543 \\
\hline & 1434 & 34 & 28,73 & 32,35 & 3.858 & 3.272 & 2.944 & 2.617 \\
\hline
\end{tabular}

Şekil 3. SİLO Teknik Kataloğu. 
Büro çalışmaları aşamasında İHA ile elde edilen fotoğraflar ve yer kontrol noktaları Pix4Dmapper, Agisoft Metashape ve 3 DF Zephyr programları değerlendirilerek nokta bulutları, mesh modeller ve 3 boyutlu modeller üretilmiştir.

Hacim hesabı yapılacak çalışma alanında toplam 24 adet aynı kapasite ve ölçülere sahip SİLO bulunmaktadır. SÍLO’ların birbirine çok yakın olması 3 boyutlu model oluşturmada ve hacim hesaplama işleminde olumsuz sonuçlara neden olmaktadır.

SİLO'nun taban alanın çevrelenmesinde SİLO'lar arası mesafenin çok yakın olması ve SíLO'lar üzerinde yer alan boşaltım tünellerinin oluşturulan üçgen yüzeye dahil edilmesi nedeniyle programlar bünyesinde yer alan Hacim Hesaplama Modülün yüksek hatalı sonuç verdiği görülmüştür. Bu nedenle SİLO'ların hacim hesaplama işlemleri aşağıda belirtilen şekilde yapılmıştır.

Hacmi hesaplanacak SÍLO'lar geometrik olarak taban kotundan saçak yüksekliğine kadar silindir; saçak yüksekliğinden tepe yüksekliğine kadar konik yüzey şekline sahiptir. $\mathrm{Bu}$ nedenle hacim hesaplanması aşamasında aşağıda Şekil 4' te gösterildiği üzere silindir hacmi formülü (1) ve Şekil 5'te gösterildiği üzere konik yüzey hacmi formülü (2) ile hesaplanmıștır.

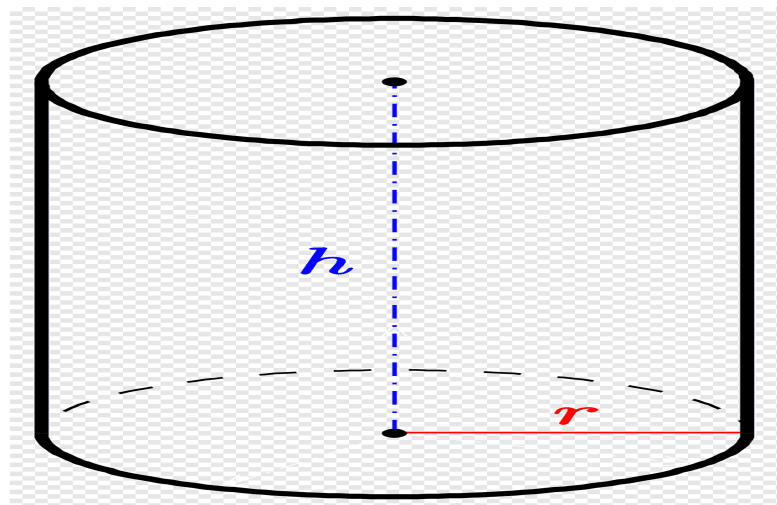

Şekil 4. Silindir Prizma Yüzeyi.

Silindir prizma hacim formülü ise aşağıda belirtilmiştir:

$$
V_{\text {silindir }}=\pi r^{2} h
$$

Burada $h$ taban kotundan saçak yüksekliğine kadar olan yükseklik, $r$ ise taban yarıçapıdır.

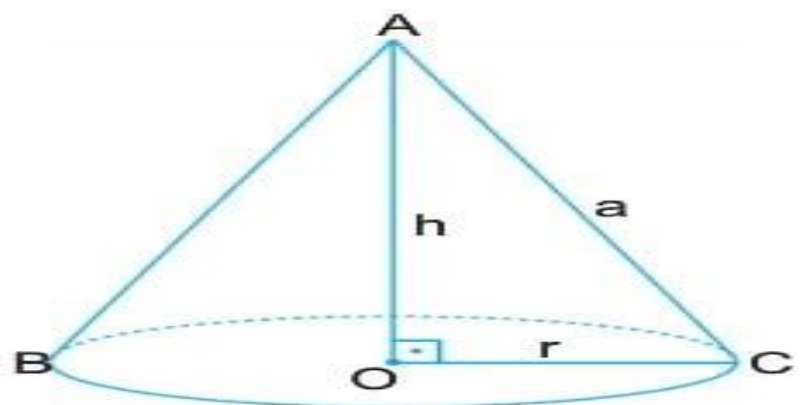

Şekil 5. Dik Konik Prizma Yüzeyi.

Dik konik prizma hacim formülü ise aşağıda belirtilmiştir:

$$
V_{k o n i}=\frac{1}{3} \pi r^{2} h
$$

Burada $h$ tepe noktası ile saçak yüksekliği arasındaki yükseklik farkı, $r$ ise taban yarıçapıdır.

Yukarıda Silindir prizma hacim formülü (1) ve dik konik prizma hacim formülünde (2) ihtiyaç duyulan tepe noktası, saçak yüksekliği ve taban yarıçapı ölçülerine, arazi çalışmasında esnasında tesis edilen yer kontrol noktaları ve İHA ile çekilen fotoğrafların Pix4Dmapper, Agisoft Metashape ve 3 DF Zephyr programlarında değerlendirilmesi ile üretilen 3 boyutlu modeller kullanılarak ulaşılmış olup, aşağıda Bulgular başlığı altında detaylı olarak açıklanmıştır.

\subsection{Dolgu Alanı Hacim Hesabı}

İHA'ların hacim hesaplarında kullanılabilirliğinin araştırılmasında ikinci işlem dolgu alanında malzeme taşınarak gerçekleştirilen hacim hesaplaması işlemidir. Yapılan hacim hesaplama ișlemi arazi çalıșması ve büro çalışması olmak üzere iki aşamadan oluşmakta olup, aşağıda açıklanmıştır.

\subsubsection{Arazi Çalışması}

Yapılan ikinci hacim hesaplama ișleminde Melikgazi Belediyesi'ne ait Asfalt Üretim Tesisleri çalışma alanı olarak belirlenmiştir. Proje için seçilen saha devamlı olarak ana malzeme depolanmasının ve üretiminin yapıldığı tesis olup, tesis içerisinden düz bir zemin yapısına sahip bölge belirlenmiş ve çalışma alanına ait uydu görüntüsü Şekil 6'da verilmiştir.

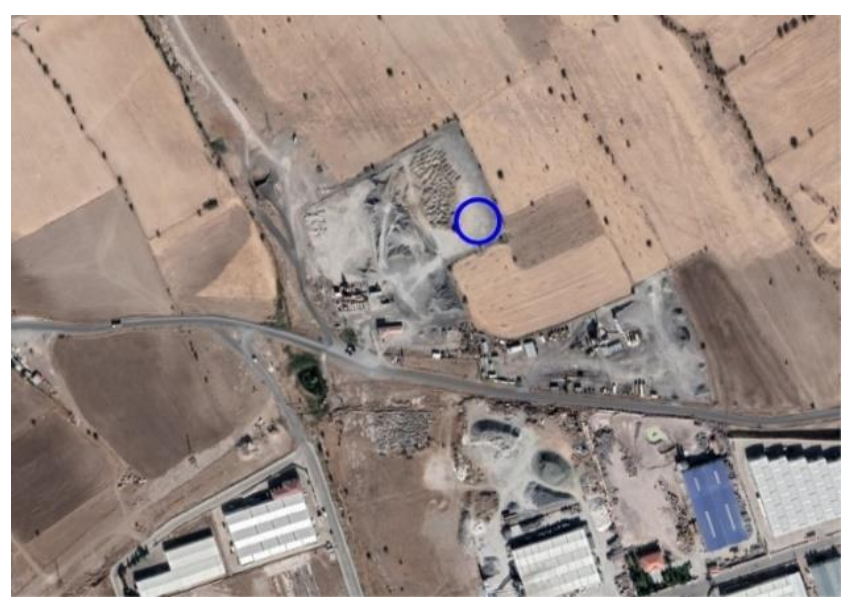

Şekil 6. Dolgu Çalışma Alanı Uydu Görüntüsü.

Yapılan arazi çalışmasında ilk işlem olarak Comnav T300 marka GPS ile 4 adet yer kontrol noktası tesis edilmiş olup, Tablo 2'de gösterildiği üzere verilmiştir.

Tablo 2. Dolgu Alanı Hacim Hesabı İçin Tesisi Edilen Yer kontrol Noktaları.

\begin{tabular}{rlll}
\hline \multicolumn{1}{l}{ YKN NO } & X DEĞERİ & Y DEĞERI & Z DEĞERİ \\
\hline P.101 & 467297.800 & 4287364.772 & 1419.735 \\
P.102 & 467310.438 & 4287370.688 & 1419.801 \\
P.103 & 467317.176 & 4287350.383 & 1420.075 \\
P.104 & 467287.657 & 4287337.396 & 1419.401 \\
\hline
\end{tabular}


Ayrıca arazi çalışması esnasında dolgu alanında yapılacak hacim hesaplamalarının yüksek doğrulukta hesaplanabilmesi için çalışma yapılacak bölgenin karakteristik noktalarının (tepe noktası, dere yatağl, yamaç kısmı vb.) ölçümleri de gerçekleştirilmiştir. Yapılan bu ölçümler sayesinde büro çalışması esnasında Pix4Dmapper, Agisoft Metashape ve 3 DF Zephyr programlarında oluşturulacak üçgen yüzeylerin hatalı yüzey oluşturulması en düşük seviyeye indirgenerek, programlarda elde edilecek Sayısal Yükseklik Modellerinin yüksek doğrulukta elde edilmesi amaçlanmıştır.

Yer kontrol noktaları tesisi tamamlandıktan sonra DJI Phantom 4 Pro marka İHA kullanılarak çalışma alanında hacim hesabı yapılacak malzemenin taşınmasından önce ve hacim hesabı yapılacak malzemenin taşınmasının ardından 2 kez uçuş yapılmış ve hava fotoğrafları çekimi tamamlanmıştır. İşlem esnasında İHA ile 50 metre yükseklikten \%80 ön ve \%60 yan bindirme oranı ile ilk uçuşta 111 adet ve ikinci uçuşta 115 adet olmak üzere toplam 226 adet fotoğraf elde edilmiştir. Uçuş işlemlerinde kullanılan DJI Phantom 4 Pro marka İHA'nın sağladığı yer örnekleme aralığının (m / 36.5) cm / piksel olduğu teknik kataloğu üzerinden incelenmiștir. Çalıșma kapsamında yapılan uçuşun $50 \mathrm{~m}$ yükseklikten gerçekleştirilmiş olması nedeniyle yer örnekleme aralığı $1.40 \mathrm{~cm} /$ piksel olarak kabul edilmiştir. İHA ile yapılan uçuşlara ait örnek fotoğraf Şekil 7’ de verilmiştir.

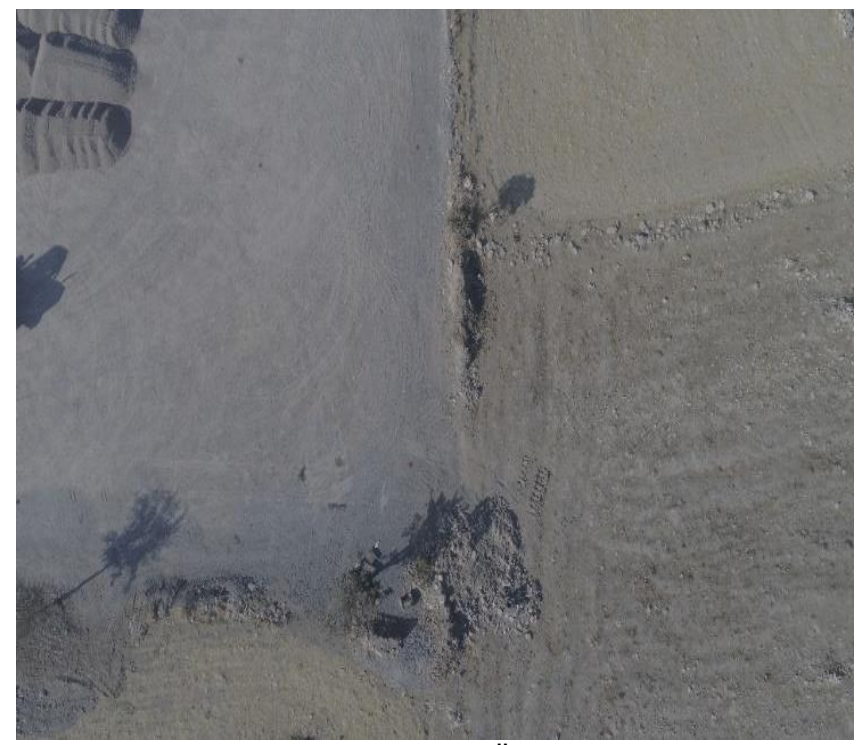

Şekil 7. Çalışma Alanının Dolgu Öncesi Görünümü.

Arazi çalışması esnasında çalışma alanı boş iken İHA ile yapılan uçuş tamamlandıktan sonra çalışma alanına 2 ayrı araç ile malzeme taşınması yapılmıştır. Kullanılan araçlara kantar ile tonaj hesabı yapılmış ve ilk araçla taşınan malzemenin $22.700 \mathrm{~kg}$ olduğu, ikinci araç ile taşınan malzemenin ise $49.600 \mathrm{~kg}$ olduğu tespit edilmiştir. Çalışma alanına taşınan malzemeye ait görsel Şekil 8'de verilmiştir.

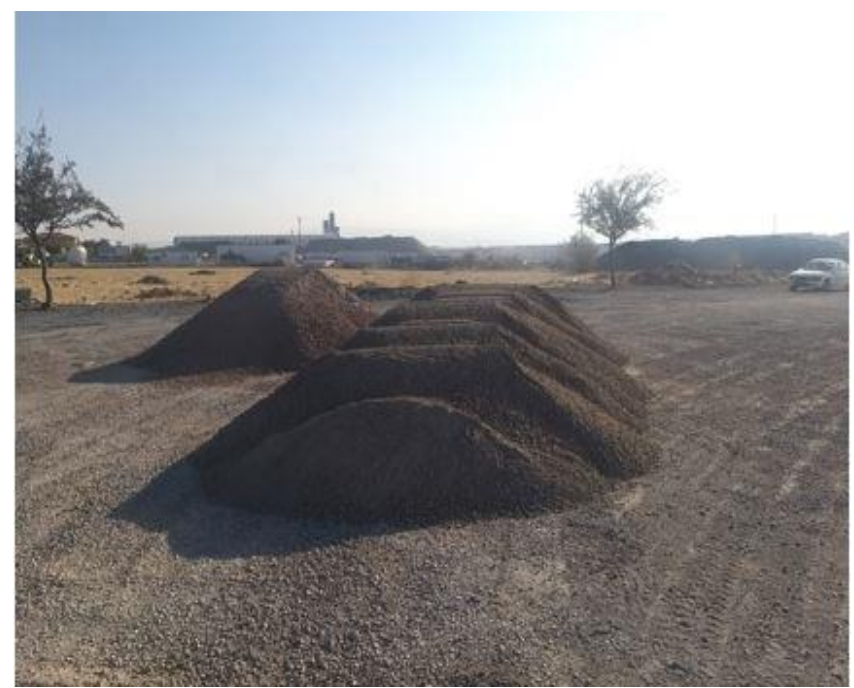

Şekil 8. Çalışma Alanına Taşınan Malzeme.

Malzeme taşıma işlemi tamamlandıktan sonra hacim hesabı yapılabilmesi için malzemenin yoğunluk bilgisine ihtiyaç duyulmuştur. Hacim hesabı yapılacak malzemenin aynı ebat ve ölçülerde homojen olmayan yapıya sahip olması nedeniyle yoğunluk hesabı yapılabilmesi için dikdörtgen prizma yüzey yapısına sahip bir adet eni $11.6 \mathrm{~cm}$, boyu $15 \mathrm{~cm}$ ve yüksekliği 31 cm olan yağ tenekesi kullanılmıştır. Söz konusu tenekeye malzemeden doldurulmuş, kantar vasitasıyla ağırlığı ölçülmüş ve 9.35 kg olarak ölçülmüştür.

Yapılan ölçüm sonucu aşağıda (3)'te gösterildiği üzere dikdörtgen prizma hacim hesaplama formülünde kullanılarak malzemenin hacmi hesaplanmış ve (4)'te belirtilen yoğunluk formülü yardımıyla malzemenin yoğunluğuna ulaşılmıştır.

Dikdörtgen prizmanın hacim formülü aşağıda gösterilmiştir:

$$
V=a \times b \times c
$$

$\mathrm{Bu}$ formülde $a$ dikdörtgen prizmanın boyu, $b$ dikdörtgen prizmanın eni, $c$ ise dikdörtgen prizmanın yüksekliğidir.

Malzemenin yoğunluğu aşağıda belirtildiği şekilde hesaplanmıştır;

$$
C=\frac{m}{v}
$$

Bu formülde $C$ yoğunluk, $m$ malzemenin kütlesi, $v$ ise malzemenin hacmidir.

$$
\begin{gathered}
C=\frac{9.35 \mathrm{~kg}}{(11,6 \mathrm{~cm} \times 31 \mathrm{~cm} \times 15 \mathrm{~cm})} \\
C=0.001733 \mathrm{~kg} / \mathrm{cm}^{3}
\end{gathered}
$$

olarak hesaplanmıştır. Yoğunluk birimi ton birimine uyarlanması yapılmış ve $C=1.73$ ton $/ \mathrm{m}^{3}$ olarak tespit edilmiştir. 
Çalıșma alanına tașınan malzemenin toplam hacmine ise (4)'te belirtilen yoğunluk formülü kullanılarak ulaşılmış olup, așağıda belirtildiği șekilde hesaplanmıştır;

$$
\begin{gathered}
C=\frac{m}{v} \\
1.73 \text { ton } / \mathrm{m}^{3}=\frac{(22.700 \mathrm{~kg}+49.600 \mathrm{~kg})}{v} \\
v=\frac{(22.700 \mathrm{~kg}+49.600 \mathrm{~kg})}{1.73 \mathrm{ton} / \mathrm{m}^{3}} \\
v=41.79 \mathrm{~m}^{3} \text { olarak hesaplanmıştır. }
\end{gathered}
$$

Bu formülde $C$ hesaplanan malzeme yoğunluğu, $m$ ise çalıșma alanına tașınan malzemenin toplam kütlesidir.

\subsubsection{Büro Çalışması}

Büro çalıșmasında ilk olarak arazi çalışması ile elde edilen ve yukarıda Tablo 2'de gösterilen yer kontrol noktaları Pix4Dmapper, Agisoft Metashape ve 3 DF Zephyr programlarına aktarılmış ve hata payları incelenmiștir. Yapılan incelemede yer kontrol noktalarının Pix4Dmapper programında ortalama $\mathrm{X}$ değeri hata payı $\sim 0.2 \mathrm{~cm}, \mathrm{Y}$ değeri hata payı $\sim 0.5 \mathrm{~cm}$ ve $\mathrm{Z}$ değeri hata payı ise $\sim 1.7 \mathrm{~cm}$ olarak tespit edilmiştir. Agisoft Metashape programinda ise yer kontrol noktalarının nihai ortalama hata payı $\sim 1 \mathrm{~cm}, 3 \mathrm{DF}$ Zephyr programında ise yer kontrol noktalarının nihai ortalama hata payı $\sim 1.1 \mathrm{~cm}$ olarak tespit edilmiştir.

Arazi çalışmaları sonucu elde edilen iki ayrı uçuş verileri ofis ortamında 3 boyutlu modellerin üretilmesi aşamasında kullanılmıştır. 3 boyutlu modellerin elde edilmesi ve hacim hesabının yapılması için Pix4Dmapper, Agisoft Metashape ve 3 DF Zephyr programları kullanılmıştır. Söz konusu programlarda çalışma alanı boş iken ve çalıșma alanına malzeme taşındıktan sonra elde edilen veriler kullanılarak 2 ayrı yüzey modellemesi yapılmış ve Sayısal Yükseklik Modelleri elde edilmiştir. Ancak Pix4Dmapper, Agisoft Metashape ve 3 DF Zephyr programları yazılımsal olarak tek yüzey üzerinde hacim hesaplama özelliğine sahiptir. Ancak dolgu alanında yapılan çalışma kapsamında 2 ayrı Sayısal Yükseklik Modelinin üstü üste çakıştırılarak hacim hesaplaması yapılacak olması nedeniyle Sayısal Yükseklik Modeli verileri Global Mapper programında değerlendirilmiş ve hacim hesaplamaları yapılmıştır. Sayısal Yükseklik Modellerinden bir örnek aşağıda belirtildiği üzere Șekil 9'da gösterilmiștir.

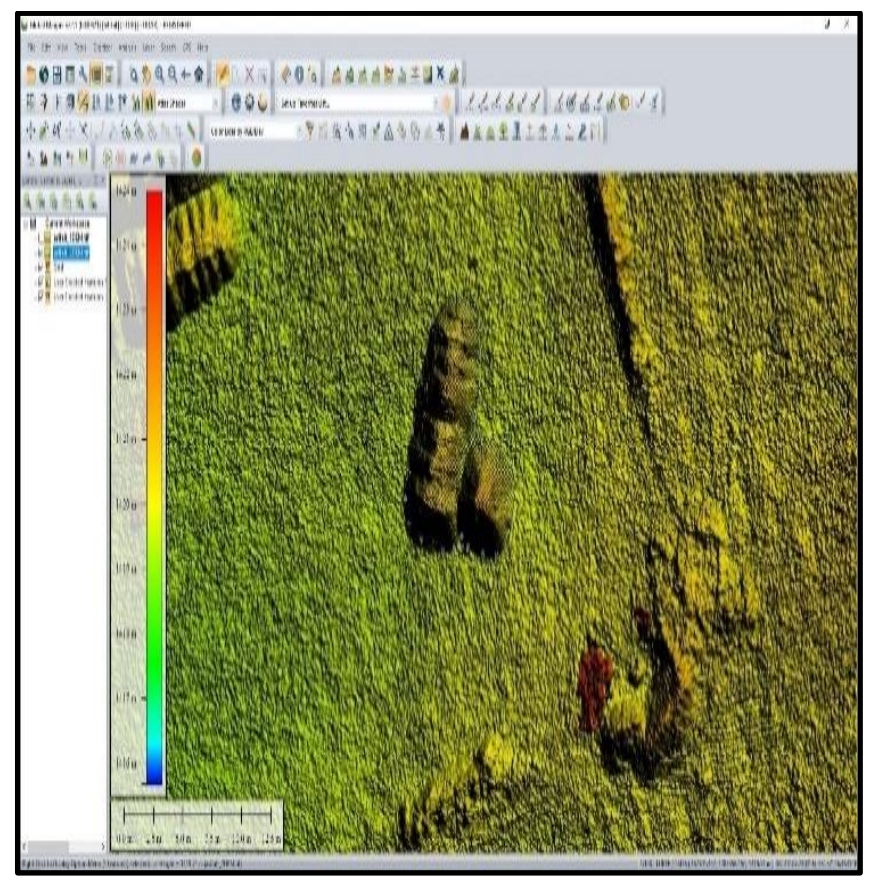

Şekil 9. Agisoft Metashape Programında Üretilen ve Global Mapper Programına Aktarılan Sayısal Yükseklik Modeli.

Yapılan çalışmaya ait elde edilen sonuçlar aşağıda Bulgular başlığı altında detaylı olarak açıklanmıștır.

\section{BULGULAR}

Calıșma kapsamında iki ayrı hacim hesaplama ișlemi bulunmakta olup, bu bölümde ilk olarak SíLO hacim hesabı işlemi açıklanmıștır. Yapılan büro çalışması ile elde edilen bilgiler Tablo 3'te gösterildiği üzere verilmiştir.

Tablo 3. SİLO Hacim Hesabı İşleminde Büro Çalışması İle Elde Edilen Değerler.

\begin{tabular}{lllll}
\hline & $\begin{array}{l}\text { Taban } \\
\text { Capi } \\
(\mathrm{m})\end{array}$ & $\begin{array}{l}\text { Saçak } \\
\text { Yüksekliği } \\
(\mathrm{m})\end{array}$ & $\begin{array}{l}\text { Tepe } \\
\text { Yüksekliği } \\
(\mathrm{m})\end{array}$ & $\begin{array}{l}\text { Kapasite } \\
\left(\boldsymbol{m}^{3}\right)\end{array}$ \\
\hline $\mathrm{A}$ & 12.83 & 12.68 & 16.29 & 1782 \\
$\mathrm{~B}$ & 12.77 & 12.47 & 16.48 & 1765.54 \\
FARK & -0.06 & -0.21 & 0.19 & -16.46 \\
\hline $\mathrm{A}$ & 12.83 & 12.68 & 16.29 & 1782 \\
$\mathrm{C}$ & 12.72 & 12.96 & 16.56 & 1765.54 \\
FARK & -0.11 & 0.28 & 0.27 & -16.46 \\
\hline A & 12.83 & 12.68 & 16.29 & 1782 \\
D & 12.87 & 13.00 & 16.86 & 1855.67 \\
FARK & 0.04 & 0.32 & 0.57 & 73.67 \\
\hline
\end{tabular}


Tablo 3'te A satırı SíLO'ların teknik katalog bilgilerini, B satırı Pix4Dmapper programı ile elde edilen değerleri, C satırı 3 DF Zephyr programı ile elde edilen değerleri, D satırı ise Agisoft Metashape programı ile elde edilen değerleri göstermektedir.

SİLO'ların hacim hesaplama işlemi ilk olarak Pix4Dmapper programında gerçekleștirilmiştir. Pix4Dmapper programında arazi çalışması ile elde edilen yer kontrol noktaları ve İHA ile çekilen fotoğraflar kullanılarak nokta bulutu, mesh model ve 3 boyutlu model elde edilmiştir. Daha sonra Pix4Dmapper programında yer alan ölçüm aracı ile sırasıyla taban çapı, saçak yüksekliği ve tepe yükseklikleri ölçülmüştür.

İlk olarak Pix4Dmapper programı ile elde edilen 3 boyutlu modelde taban çapı birkaç ayrı noktadan hesaplanmış ve ortalama 13.10 m olarak bulunmuş olup, bu sonuca diştan dışa ölçüm ile ulaşılmıştır. Hacmi hesaplanacak SİLO'ların teknik verilerine göre $65 \mathrm{~mm}$ sac kaplama ve $10 \mathrm{~cm}$ şerit mastikler bulunmaktadır. Bu veriler her iki taraftan Pix4Dmapper programı ile elde edilen diştan dişa ölçüm sonucundan çıkarılarak silonun taban çapı $12.77 \mathrm{~m}$ olarak hesaplanmış ve yapılan hesaplama SİLO teknik kataloğunda yer alan taban çapı ile kıyaslanarak -0.06 m hata payına sahip olduğu görülmüştür.

Saçak yüksekliği Pix4Dmapper programında zemin noktasından 15. Ring bölümünün üst sınırına kadar olan yükseklik olarak kabul edilerek saçak yüksekliği 12.47 m olarak hesaplanmış ve yapılan hesaplama SíLO teknik kataloğunda yer alan saçak yüksekliği ile kıyaslanarak $0.21 \mathrm{~m}$ hata payına sahip olduğu görülmüștür.

Tepe Yüksekliğinin bulunmasında ise Pix4Dmapper programında SİLO'nun en üst kısmında bir adet nokta atılmış ve kotu incelenmiştir. Bu işlem ile atılan noktanın kotu 1608.88 olarak hesaplanmıştır. Aynı hesaplama işlemi esnasında SíLO'nun taban kotunun ise 1592.40 olduğu görülmüş olup, tepe noktasının yüksekliği iki kotun farkı alınarak 16.48 m olarak hesaplanmıştır. Yapılan hesaplama sonucu SíLO teknik kataloğunda yer alan tepe yüksekliği ile kıyaslanarak +0.19 m hata payına sahip olduğu görülmüştür.

Pix4Dmapper programı ile elde edilen taban çapı, saçak yüksekliği ve tepe yüksekliği ölçülerinden faydalanılarak yukarıda (1)'de belirtilen silindir prizma hacim formülü ve (2)'de dik konik prizma hacim formülünde kullanılarak SİLO'nun hacmi hesaplanmış ve $1.765,54 \mathrm{~m}^{3}$ olarak tespit edilmiștir. Yapılan hesaplama sonucu SİLO teknik kataloğunda yer alan kapasite verisi ile kıyaslanarak -16.46 $\mathrm{m}^{3}$ hata payına sahip olduğu görülmüştür. Pix4Dmapper programında elde edilen hacim hesabının doğruluk oranı aşağıda (5)'te belirtilen doğruluk oranı formülü ile hesaplanmıștır;

$$
\begin{aligned}
& \text { Doğruluk Oranı }=\frac{V_{\text {Hesaplanan }} \cdot 100}{V_{\text {SiLO }}} \\
& \text { Doğruluk Oranı }=\frac{\left(1765.54 \mathrm{~m}^{3}\right) \cdot 100}{\left(1.782 \mathrm{~m}^{3}\right)}
\end{aligned}
$$

$$
\text { Doğruluk Oranı = \%99.07 }
$$

Yukarıdaki eşitlikten Doğruluk Oranı = \%99.07 olarak hesaplanmıştır.
Formülde belirtilen $V_{\text {Hesaplanan }}$ Pix4Dmapper programında hesaplanan hacim miktarını, $V_{S i L O}$ ise SİLO'ların teknik kapasitesinde belirtilen hacim miktarını göstermektedir.

SİLO'ların hacim hesaplaması büro çalışmasında ikinci olarak 3 DF Zephyr programında yapılmıştır. Pix4Dmapper programında yapılan işlemlerin benzeri 3 DF Zephyr programında da uygulanmış ve sırasıyla taban çapı, saçak yüksekliği ve tepe yüksekliği ölçülmüştür.

İlk olarak 3 DF Zephyr programı ile elde edilen 3 boyutlu modelde taban çapı birkaç ayrı noktadan hesaplanmış ve ortalama 13.05 m olarak bulunmuş olup, bu sonuca dıştan dışa ölçüm ile ulaşılmıştır. Hacmi hesaplanacak SILO'ların teknik verilerine göre $65 \mathrm{~mm}$ sac kaplama ve $10 \mathrm{~cm}$ şerit mastikler bulunmaktadır. $\mathrm{Bu}$ veriler her iki taraftan 3 DF Zephyr programı ile elde edilen diştan dışa ölçüm sonucundan çıarılarak silonun taban çapı $12.72 \mathrm{~m}$ olarak hesaplanmış ve yapılan hesaplama SILO teknik kataloğunda yer alan taban çapı ile kıyaslanarak $-0.11 \mathrm{~m}$ hata payına sahip olduğu görülmüştür.

Saçak yüksekliği 3 DF Zephyr programında zemin noktasından 15. Ring bölümünün üst sınırına kadar olan yükseklik olarak kabul edilerek saçak yüksekliği 12.96 m olarak hesaplanmış ve yapılan hesaplama SİLO teknik kataloğunda yer alan saçak yüksekliği ile klyaslanarak +0.28 m hata payına sahip olduğu görülmüştür.

Tepe Yüksekliğinin bulunmasında ise 3 DF Zephyr programında SİLO'nun en üst kısmında bir adet nokta atılmış ve kotu incelenmiştir. Bu işlem ile atılan noktanın kotu 1608.20 olarak hesaplanmıștır. Aynı hesaplama işlemi esnasında SİLO'nun taban kotunun ise 1591.64 olduğu görülmüş olup, tepe noktasının yüksekliği iki kotun farkı alınarak $16.56 \mathrm{~m}$ olarak hesaplanmıştır. Yapılan hesaplama sonucu SíLO teknik kataloğunda yer alan tepe yüksekliği ile kıyaslanarak $+0.27 \mathrm{~m}$ hata payına sahip olduğu görülmüştür.

3 DF Zephyr programı ile elde edilen taban çapı, saçak yüksekliği ve tepe yüksekliği ölçülerinden faydalanılarak yukarıda (1)'de belirtilen silindir prizma hacim formülü ve (2)'de dik konik prizma hacim formülünde kullanılarak SİLO'nun hacmi hesaplanmış ve $1.765,54 \mathrm{~m}^{3}$ olarak tespit edilmiştir. Yapılan hesaplama sonucu SİLO teknik kataloğunda yer alan kapasite verisi ile kıyaslanarak $-16.46 \mathrm{~m}^{3}$ hata payına sahip olduğu görülmüştür. 3 DF Zephyr programında elde edilen hacim hesabının doğruluk oranı aşağıda (5)'te belirtilen doğruluk oranı formülü ile hesaplanmıştır;

$$
\begin{aligned}
& \text { Doğruluk Oranı }=\frac{V_{\text {Hesaplanan }} \cdot 100}{V_{\text {SiLO }}} \\
& \text { Doğruluk Oranı }=\frac{\left(1765.54 \mathrm{~m}^{3}\right) \cdot 100}{\left(1.782 \mathrm{~m}^{3}\right)}
\end{aligned}
$$

$$
\text { Doğruluk Oranı = \%99.07 }
$$

Yukarıdaki eşitlikten Doğruluk Oranı = \%99.07 olarak hesaplanmıștır.

Formülde belirtilen $V_{\text {Hesaplanan }} 3$ DF Zephyr programinda hesaplanan hacim miktarını, $V_{S i L O}$ ise SILO'ların teknik kapasitesinde belirtilen hacim miktarını göstermektedir.

Hacim hesaplaması büro çalışmasında üçüncü olarak ise Agisoft Metashape programında yapılmıştır. Agisoft 
Metashape programında, Pix4Dmapper ve 3 DF Zephyr programlarında yapılan uygulamaların benzeri yapılmış ve sırasıyla taban çapı, saçak yüksekliği ve tepe yüksekliği hesaplanmıştır.

İlk olarak Agisoft Metashape programı ile elde edilen 3 boyutlu modelde taban çapı birkaç ayrı noktadan hesaplanmış ve ortalama $13.20 \mathrm{~m}$ olarak bulunmuş olup, bu sonuca diştan dışa ölçüm ile ulaşılmıştır. Hacmi hesaplanacak SİLO'ların teknik verilerine göre $65 \mathrm{~mm}$ sac kaplama ve $10 \mathrm{~cm}$ şerit mastikler bulunmaktadır. Bu veriler her iki taraftan Agisoft Metashape programı ile elde edilen dıştan dışa ölçüm sonucundan çıkarılarak silonun taban çapı 12.87 m olarak hesaplanmış ve yapılan hesaplama SİLO teknik kataloğunda yer alan taban çapı ile kıyaslanarak +0.04 m hata payına sahip olduğu görülmüștür.

Saçak yüksekliği Agisoft Metashape programında zemin noktasından 15. Ring bölümünün üst sınırına kadar olan yükseklik olarak kabul edilerek saçak yüksekliği $13.00 \mathrm{~m}$ olarak hesaplanmış ve yapılan hesaplama SíLO teknik kataloğunda yer alan saçak yüksekliği ile kıyaslanarak +0.32 $\mathrm{m}$ hata payına sahip olduğu görülmüştür.

Tepe Yüksekliğinin bulunmasında ise Agisoft Metashape programında SİLO'nun en üst kısmında bir adet nokta atılmış ve kotu incelenmiştir. Bu işlem ile atılan noktanın kotu 1608.65 olarak hesaplanmıştır. Aynı hesaplama işlemi esnasında SİLO'nun taban kotunun ise 1591.79 olduğu görülmüş olup, tepe noktasının yüksekliği iki kotun farkı alınarak $16.86 \mathrm{~m}$ olarak hesaplanmıștır. Yapılan hesaplama sonucu SİLO teknik kataloğunda yer alan tepe yüksekliği ile klyaslanarak +0.57 m hata payına sahip olduğu görülmüştür.

Agisoft Metashape programı ile elde edilen taban çapı, saçak yüksekliği ve tepe yüksekliği ölçülerinden faydalanılarak yukarıda (1)'de belirtilen silindir prizma hacim formülü ve (2)'de dik konik prizma hacim formülünde kullanılarak SİLO'nun hacmi hesaplanmış ve $1.855,67 \mathrm{~m}^{3}$ olarak tespit edilmiştir. Yapılan hesaplama sonucu SİLO teknik kataloğunda yer alan kapasite verisi ile kıyaslanarak $+73.67 \mathrm{~m}^{3}$ hata payına sahip olduğu görülmüştür. Agisoft Metashape programında elde edilen hacim hesabının doğruluk oranı aşağıda (5)'te belirtilen doğruluk oranı formülü ile hesaplanmıştır;

$$
\begin{aligned}
& \text { Doğruluk Oranı }=\frac{V_{\text {Hesaplanan }} \cdot 100}{V_{\text {SiLO }}} \\
& \text { Doğruluk Oranı }
\end{aligned}
$$

$$
\text { Doğruluk Oranı }=\% 104.07
$$

Yukarıdaki eşitlikten Doğruluk Oranı = \%104.07 olarak hesaplanmıştır.

Elde edilen hacim miktarı SİLO teknik kataloğunda belirtilen hacim miktarından fazla olması nedeniyle yüzdelik orandan \%4.07 fazla olan kısım hata payı olarak kabul edilmiş ve yüzdelik dilimden farkı alınarak doğruluk oranı \%95.87 olarak hesaplanmıştır.

Formülde belirtilen $V_{\text {Hesaplanan }}$ Agisoft Metashape programinda hesaplanan hacim miktarını, $V_{S i L O}$ ise SİLO'ların teknik kapasitesinde belirtilen hacim miktarını göstermektedir.
Calıșma Kapsamında ikinci hacim hesaplama işlemi ise dolgu alanında yapılan hacim hesabı ișlemidir.

Arazi çalışmaları sonucu elde edilen iki ayrı uçuş verileri büro ortamında 3 boyutlu modellerin üretilmesi aşamasında kullanılmıştır. 3 boyutlu modellerin elde edilmesi ve hacim hesabının yapılması için Pix4Dmapper, Agisoft Metashape ve 3DF Zephyr programları kullanılmıştır. Söz konusu programlarda çalışma alanı boş iken ve çalışma alanına malzeme taşındıktan sonra elde edilen veriler kullanılarak 2 ayrı yüzey modellemesi yapılmış ve Sayısal Yükseklik Modelleri elde edilmiştir. 3 boyutlu modellerden Pix4Dmapper programı ile elde edilen veriye ait görüntü Şekil 10’da gösterildiği üzere verilmiștir.

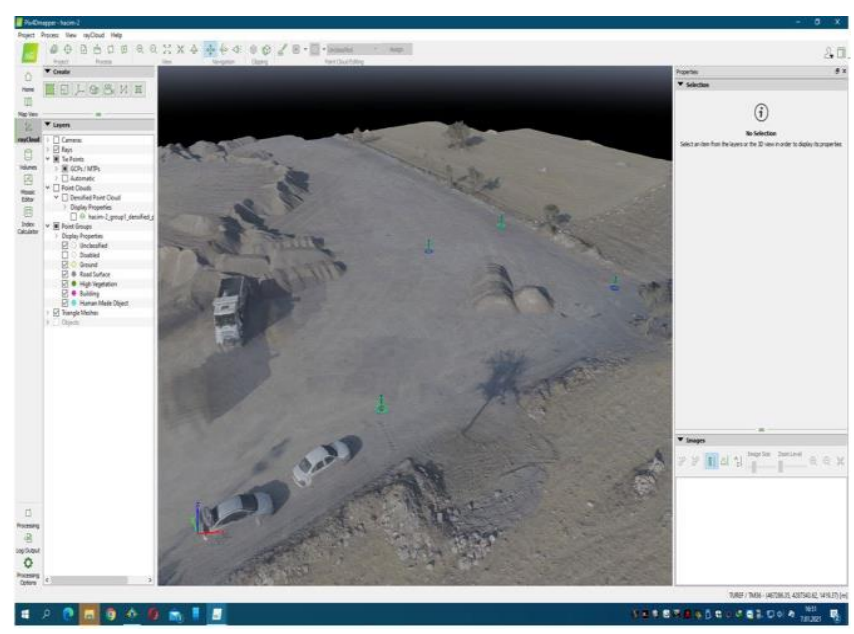

Şekil 10. Pix4Dmapper Programı İle Oluşturulan Çalışma Alanına Ait 3 Boyutlu Model.

Ancak Pix4Dmapper, Agisoft Metashape ve 3 DF Zephyr programları yazılımsal olarak tek yüzey üzerinden hacim hesaplama yeteneğine sahiptir. Ancak dolgu alanında yapılan çalıșma kapsamında 2 ayrı Sayısal Yükseklik Modelinin üstü üste çakıştırılarak hacim hesaplaması yapılacak olması nedeniyle Sayısal Yükseklik Modeli verileri Global Mapper programında değerlendirilmiş ve hacim hesaplamaları yapılmıștır.

Yapılan hacim hesaplamaları aşağıda Tablo 4'te gösterildiği üzere verilmiş ve çalışma alanına taşınan malzeme hacmi ile kıyaslanması gerçekleștirilmiştir.

Tablo 4. Dolgu Alanı Hacim Hesabı İşleminde Büro Çalışması İle Elde Edilen Değerler.

\begin{tabular}{cccc}
\hline & Pix4Dmapper & $\begin{array}{c}\text { Agisoft } \\
\text { Metashape }\end{array}$ & 3 DF Zephyr \\
\hline Hacim $\left(\boldsymbol{m}^{3}\right)$ & 43.20 & 45.44 & 44.79 \\
Malzeme & 41.79 & 41.79 & 41.79 \\
Hacmi $\left(\boldsymbol{m}^{3}\right)$ & 1.41 & 3.65 & 3.00 \\
FARK $\left(\boldsymbol{m}^{3}\right)$ & & & \\
\hline
\end{tabular}

Pix4Dmapper programında çalışma alanının boş hali ve çalışma alanına malzeme taşınmasının ardından oluşturulan Sayısal Yükseklik Modellerinin Global Mapper programında değerlendirilmesi ile Tablo 2'de gösterildiği üzere çalışma alanına taşınan malzemenin toplam hacmi $43.20 \mathrm{~m}^{3}$ olarak hesaplanmıștır. Arazi çalışması esnasında tonaj hesabı ile elde edilen veriler yardımıyla (4)'de gösterildiği üzere malzemenin toplam 
hacmi $41.79 \mathrm{~m}^{3}$ olarak tespit edilmiș ve Tablo 4'de gösterildiği üzere verilmiștir. Pix4Dmapper programı ile elde edilen toplam hacim ile malzeme hacmi arasında $+1.41 \mathrm{~m}^{3}$ fark tespit edilmiștir. Elde edilen veriler aşağıda (6)'da belirtilen hata payı formülünde değerlendirilmiştir;

$$
\begin{gathered}
\text { Hata Payı }=\frac{V_{\text {fark }} \cdot 100}{V_{O F \mathrm{I} S}} \\
\text { Hata Payı }=\frac{\left(43.20-41.79 \mathrm{~m}^{3}\right) \cdot 100}{41.79 \mathrm{~m}^{3}}
\end{gathered}
$$

$$
\text { Hata Payı }=\% 3.37
$$

Yukarıdaki eşitlikten Hata Payı $=\% 3.37$ olarak hesaplanmıștır. Yapılan hesaplama sonucu Pix4Dmapper programında elde edilen hacim miktarının yoğunluk formülü ile elde edilen sonuçtan fazla çıktığı görülmüş olup elde edilen hata payı yüzdelik dilimden çıkarılarak Pix4Dmapper programında doğruluk oranı \%96,63 olarak tespit edilmiştir. Formülde belirtilen $V_{\text {Fark }}$ Pix4Dmapper programinda elde edilen modeller yardımıla Global Mapper programında hesaplanan hacim miktarı ile yoğunluk formülü ile elde edilen hacim miktarı arasındaki farkı, $V_{O F i s}$ ise taşınan malzemenin yoğunluk formülü ile elde edilen hacim miktarını göstermektedir.

Arazi çalıșması ile elde edilen veriler büro çalıșması esnasında ikinci olarak Agisoft Metashape programında değerlendirilmiştir.

Agisoft Metashape programında çalışma alanının boş hali ve çalışma alanına malzeme taşınmasının ardından oluşturulan Sayısal Yükseklik Modellerinin Global Mapper programında değerlendirilmesi ile Tablo 2'de gösterildiği üzere çalışma alanına taşınan malzemenin toplam hacmi $45.44 \mathrm{~m}^{3}$ olarak hesaplanmıştır. Arazi çalışması esnasında tonaj hesabı ile elde edilen veriler yardımıyla (4)'te gösterildiği üzere malzemenin toplam hacmi $41.79 \mathrm{~m}^{3}$ olarak tespit edilmiş olup, Tablo 2'de gösterildiği üzere verilmiştir. Agisoft Metashape programı ile elde edilen toplam hacim ile malzeme hacmi arasında $+3.65 \mathrm{~m}^{3}$ fark tespit edilmiştir. Elde edilen veriler așağıda (6)'da belirtilen hata payı formülünde değerlendirilmiştir;

$$
\begin{gathered}
\text { Hata Payı }=\frac{V_{\text {fark }} \cdot 100}{V_{\text {OFiS }}} \\
\text { Hata Payı }=\frac{\left(45.44-41.79 \mathrm{~m}^{3}\right) \cdot 100}{41.79 \mathrm{~m}^{3}}
\end{gathered}
$$

$$
\text { Hata Payı }=\% 8.73
$$

Yukarıdaki eşitlikten Hata Payı $=\% 8.73$ olarak hesaplanmıștır. Yapılan hesaplama sonucu Agisoft Metashape programında elde edilen hacim miktarının yoğunluk formülü ile elde edilen sonuçtan fazla çıktığı görülmüş olup, elde edilen hata payı yüzdelik dilimden çıkarılarak Agisoft Metashape programında doğruluk oranı \%91,27 olarak tespit edilmiştir. Formülde belirtilen $V_{\text {Fark }}$ Agisoft Metashape programında elde edilen modeller yardımıyla Global Mapper programında hesaplanan hacim miktarı ile yoğunluk formülü ile elde edilen hacim miktarı arasındaki farkı, $V_{O F i s}$ ise taşınan malzemenin yoğunluk formülü ile elde edilen hacim miktarını göstermektedir.

Büro çalışmasında üçüncü olarak 3 DF Zephyr programı kullanılmıștır.

3 DF Zephyr programında çalıșma alanının boş hali ve çalışma alanına malzeme taşınmasının ardından oluşturulan Sayısal Yükseklik Modellerinin Global Mapper programında değerlendirilmesi ile Tablo 2'de gösterildiği üzere çalışma alanına taşınan malzemenin toplam hacmi $44.79 \mathrm{~m}^{3}$ olarak hesaplanmıștır. Arazi çalışması esnasında tonaj hesabı ile elde edilen veriler yardımıyla (4)'te gösterildiği üzere malzemenin toplam hacmi $41.79 \mathrm{~m}^{3}$ olarak tespit edilmiş Tablo 2'de gösterildiği üzere verilmiştir. 3 DF Zephyr programı ile elde edilen toplam hacim ile malzeme hacmi arasında $+3.00 \mathrm{~m}^{3}$ fark tespit edilmiştir. Elde edilen veriler aşağıda (6)'da belirtilen hata payı formülünde değerlendirilmiştir;

$$
\begin{gathered}
\text { Hata Payı }=\frac{V_{\text {fark }} \cdot 100}{V_{O F \mathrm{I} S}} \\
\text { Hata Payı }=\frac{\left(44.79-41.79 \mathrm{~m}^{3}\right) \cdot 100}{41.79 \mathrm{~m}^{3}} \\
\text { Hata Payı }=\% 7.18
\end{gathered}
$$

Yukarıdaki eşitlikten Hata Payı =\%7.18 olarak hesaplanmıştır. Yapılan hesaplama sonucu 3 DF Zephyr programında elde edilen hacim miktarının yoğunluk formülü ile elde edilen sonuçtan fazla çıktığı görülmüş olup elde edilen hata payı yüzdelik dilimden çıkarılarak 3 DF Zephyr programında doğruluk oranı \%92,82 olarak tespit edilmiştir. Formülde belirtilen $V_{\text {Fark }} 3$ DF Zephyr programında elde edilen modeller yardımıyla Global Mapper programinda hesaplanan hacim miktarı ile yoğunluk formülü ile elde edilen hacim miktarı arasındaki farkı, $V_{O F i s}$ ise taşınan malzemenin yoğunluk formülü ile elde edilen hacim miktarını göstermektedir.

Çalışma kapsamında yapılan hacim hesaplamaları ve Literatürde Yılmaz vd. (2018) ile Kaya vd. (2019) tarafından yapılan çalışmalar ile de belirtildiği üzere İHA verilerinin hacim hesaplarında kullanılabilirliğinin hız, maliyet ve hassasiyet yönlerinden sağladığı avantajlar sayesinde yol projeleri, kadastral detay ölçümleri, kübaj hesabı vb. mühendislik projelerinde rahatlıkla kullanılabilir olduğu kanaatine varılmıştır.

\section{SONUÇLAR}

Gelișen teknolojik gelişmeler ıșığında sivil ve askeri alanda İHA kullanımı her geçen gün yaygınlaşmaktadır. Erişilmesi zor ve insan sağlığı açısından riskli bölgelerde sağladığı kolaylık, ișlemlerin zaman açısından kısa sürelerde gerçekleştirilmesi, hassasiyet ve ekonomik yönlerden sağladı̆̆ı imkanlar sayesinde mühendislik işlemlerinde İHA'ların kullanımı son yıllarda hızla artmaktadır.

Mühendislik projelerinde hacim hesaplamaları son derece önemli işlemler arasında yer almaktadır. Hacim 
hesaplamaları günümüzde maden işletmelerinde, inşaat çalışmalarında, yol projeleri gibi çeșitli işlemlerde kullanılmaktadır.

Çalışma kapsamında fotogrametrik yöntem ile hacim hesabı araştırması yapılmış ve hacmi bilinen yapılar ve dolgu alanında hacim hesaplama işlemlerinde İHA verilerinin kullanılabilirliği araştırılmıştır. İHA ile elde edilen veriler 3 ayrı modelleme yazılımlarında değerlendirilmiş ve elde edilen sonuçlar karşılaştırılmıştır.

Çalıșma kapsamında ilk olarak hacmi bilinen tarımsal depolama tesisi SíLO'ların hacim hesabı yapılmıştır. Yapılan arazi ve büro çalışmaları neticesinde elde edilen sonuçlar SİLO'ların teknik kataloğunda belirtilen hacim kapasitesiyle karşılaştırılmıştır. Arazi çalışmasında elde edilen veriler büro çalışması esnasında 3 ayrı yazılım programında değerlendirilmiştir. Verilerin Pix4Dmapper yazılımında değerlendirilmesiyle SİLO'ların hacim miktarında elde edilen doğruluk oranı \%99.07, 3 DF Zephyr programında SİLO'ların hacim miktarında elde edilen doğruluk oranı \%99.07 ve Agisoft Metashape programında SİLO'ların hacim miktarında elde edilen doğruluk oranı \%95.87 olarak hesaplanmıștır. 3 programda elde edilen doğruluk oranının ise ortalama \%98 olduğu tespit edilmiștir.

Çalışma kapsamında ikinci olarak ise dolgu alanında hacim hesaplaması yapılmıştır. Yapılan arazi ve büro çalışmaları neticesinde elde edilen sonuçlar çalışma alanına getirilen malzemenin tonaj hesabı ve yoğunluk formülü ile elde edilen toplam hacmi karşılaştırılmıştır. Arazi çalışmasında elde edilen veriler büro çalışması esnasında 3 farklı yazılım programında değerlendirilmiştir. İlk olarak verilerin Pix4Dmapper yazılımında değerlendirilmesiyle dolgu alanında gerçekleştirilen hacim hesaplaması işleminde doğruluk oranı \%96.63, ikinci olarak verilerin 3 DF Zephyr programında dolgu alanı hacim miktarında elde edilen doğruluk oranı \%92.82 ve üçüncü olarak verilerin Agisoft Metashape programında dolgu alanı hacim miktarında elde edilen doğruluk oranı \%91.27 olarak hesaplanmıştır.

Çalışma sonucunda 3 programda elde edilen doğruluk oranının ise ortalama \%93.57 olduğu tespit edilmiştir.

Özellikle hacmi bilinen yapılarda İHA verileri ile elde edilen hacim değerlerinin yüksek doğruluk sağladığı görülmüştür. Dolgu alanlarında ise hacmi hesaplanacak malzemenin aynı yoğunlukta olmaması, geometrik olarak düzgün bir yüzey şeklinde olmaması gibi nedenlerden dolayı İHA verileri ile yapılan hacim hesaplamalarının doğruluk oranının hacmi bilinen yapılara göre daha düşük olduğu sonucuna ulaşılmıştır. $\mathrm{Bu}$ nedenle dolgu alanlarında İHA verileri ile yapılacak hacim hesaplarında aynı yoğunluğa sahip homojen objelerde daha yüksek doğruluk oranına sahip olacağı sonucuna ulaşılmıştır. Ayrıca İHA'ların uçuş süresi, rüzgârlı, yağmurlu veya karlı havalarda uçuş yapılamaması ile iletişim ve veri akışının kesilmesi gibi dezavantajları nedeniyle uygun uçuş şartlarının sağlanmasının gerekli olduğu görülmüştür.

\section{Bilgilendirme/Teşekkür}

"Hacim Hesaplarında İnsansız Hava Aracı (İHA) Verilerinin Kullanılabilirliğinin Araştırılması" adlı çalışmam boyunca danışmanım olarak araştırmalarımı yönlendiren, bilgi ve birikimlerini çalışmam boyunca esirgemeyen, vizyonu ile ufkumuzu aydınlatan çok saygı değer hocam Prof.Dr. H. Murat Yılmaz'a ve Çalışma kapsamında sağladıkları destekten dolayı Ruhbaş Tarım Ürünleri Lisanslı Depoculuk A.Ş. ortaklarından sayın Şaban Yılmaz'a teşekkür ederim.

\section{Yazarların Katkısı}

Yapılan hacim hesaplama çalışmaları kapsamında arazi ve büro çalışmaları yazar Vahit Şahin tarafından yürütülmüş olup, kontrol işlemleri yazar Prof.Dr. H. Murat Yılmaz tarafından gerçekleştirilmiştir.

\section{Çıkar Çatışması Beyanı}

Yazarlar arasında herhangi bir çıkar çatışması bulunmamaktadır.

\section{Araştırma ve Yayın Etiği Beyanı}

Yapılan çalışmada araştırma ve yayın etiğine uyulmuştur.

\section{KAYNAKÇA}

Aktaş H, Çınar M C, Birdal A C \& Türk T (2016). İnsansız Hava Araçları (İHA) İle Elde Edilen Verilerin Değerlendirilmesinde Yaygın Kullanılan Yazılımların Karşılaştırılması. Uzaktan AlgılamaCBS Sempozyumu, Cumhuriyet Üniversitesi, Sivas.

Becker C, Rosinskaya E, Häni N, d'Angelo E \& Strecha C (2018). Classification of Aerial Photogrammetric 3D Point Clouds. Photogrammetric Engineering \& Remote Sensing, 84, 287-295.

Gençerk E Y (2016). İnsansız Hava Aracı Fotogrametrisi Uygulaması ile İnşaat Projesi İmalat Durumunun Araştırılması. Yüksek Lisans Tezi, İstanbul Teknik Üniversitesi Fen Bilimleri Enstitüsü, İstanbul.

Kaya Y, Şenol H İ, Memduhoğlu A, Akça Ş, Ulukavak M \& Polat N (2019). Hacim Hesaplarında İHA Kullanımı. Osmanbey Kampüsü Örneği. Türkiye Fotogrametri Dergisi, 1(1), 07-10.

Özemir I \& Uzar M (2016). İHA İle Fotogrametrik Veri Üretimi. VI. UZAL-CBS Sempozyumu, Adana.

Saripalli S, Montgomery J F \& Sukhatme G S (2003). Visually Guided Landing of an Unmanned Aerial Vehicle. IEEE Transactions on Robotics and Automation, 19(3), 371-380.

Seki M (2017). İnsansız Hava Araçlarının Hacim Hesaplarında Kullanılabilirliği. Yüksek Lisans Tezi, Afyon Kocatepe Üniversitesi, Afyon. 
Takeuchi D \& Nakanishi S (2019). An Artificial Neural Network Model to Estimate Grain Size on a River Bed From UAV Photographs and DEMs.

Tercan E (2018). Karayolu Ölçmelerinde İnsansız Hava Araçlarının Kullanılması: Okurcalar Şehir Merkezi Örneği. Ömer Halisdemir Üniversitesi Mühendislik Bilimleri Dergisi, 7(2), 649-660.

Torun A (2017). İnsansız Hava Aracı (İHA) Sektöründe Trend: İHA Fotogrametrisi Bakışıyla. Afyon Kocatepe Üniversitesi Fen ve Mühendislik Bilimleri Dergisi, Özel Sayı, 35-52.

Ulvi A (2018). Analysis of the Utility of the Unmanned Aerial Vehicle (UAV) in Volume Calculation by Using Photogrammetric Techniques. International Journal of Engineering and Geosciences, 3(2), 43-49.

Ulvi A, Yakar M, Yiğit A Y \& Kaya Y (2020). İHA ve Yersel Fotogrametrik Teknikler Kullanarak Aksaray Kızll Kilise'nin 3 Boyutlu Nokta Bulutu ve Modelinin Üretilmesi. Geomatik Dergisi, 5(1), 19-26.

Uysal M, Toprak A S \& Polat N (2015). İnsansız Hava Araçları İle Sayısal Arazi Modeli Üretimi. VIII. TUFUAB Teknik Sempozyumu, Konya, Türkiye.

Yakar M \& Doğan Y (2017). Silifke Așağı Dünya Obruğunun İHA Kullanılarak Üç Boyutlu Modellenmesi. Afyon Kocatepe Üniversitesi Fen ve Mühendislik Bilimleri Dergisi, özel sayı, 94-101.
Yakar M, Toprak A S, Ulvi A \& Uysal M (2015). Konya Beyșehir Bezariye Hanının(Bedesten) İHA ile Fotogrametrik Teknik Kullanılarak Üç Boyutlu Modellenmesi. 15. Harita Bilimsel ve Teknik Kurultayı, Ankara.

Yakar M, Yılmaz H M \& Mutluoğlu H M (2009). Hacim Hesaplamalarında Laser Tarama ve Yersel Fotogrametrinin Kullanılması. TMMOB Harita ve Kadastro Mühendisleri Odası, 12. Türkiye Harita Bilimsel ve Teknik Kurultayı, Ankara.

Yakar M, Yilmaz H M \& Mutluoglu O (2010). Comparative Evaluation of Excavation Volume by TLS and Total Topographic Station Based Methods. Lasers in Engineering 19(5-6), 331-345.

Yanmaz E, Yahyanejad S, Rinner B, Hellwagner H \& Bettstetter C (2017). Drone Networks: Communications, Coordination, and Sensing. Ad Hoc Networks, doi: 10.1016/j.adhoc 2017. 09.001.

Yilmaz H M \& Yakar M (2008). Computing of Volume of Excavation Areas by Digital Close Range Photogrammetry. Arabian Journal for Science and Engineering 33(1A), 63-79.

Yılmaz H M, Mutluoğlu Ö, Ulvi A, Yaman A \& Bilgilioğlu S $S$ (2018). İnsansız Hava Aracı ile Ortofoto Üretimi ve Aksaray Kampüsü Örneği. Geomatik Dergisi, 3(2), 129-136. 